\title{
Teses de Doutorado
}

Contribuições - Natureza e Finalidade (Contribuição a uma Teoria Finalística do Direito Tributário

Por Ígor Danilevicz

Data da defesa da tese: 23/03/2007

Orientador: Cezar Saldanha Souza Junior

A tese procura identificar a natureza $e$ a finalidade das contribuições. Utiliza, para isso, de um processo reflexivo com fundamento na tradição do realismo teleológico filosófico grego, que passou pelos romanos e foi enriquecido pela reflexão medieval. Isso contribui de um modo efetivo a uma teoria finalística do Direito Tributário. As contribuições tratadas na tese são identificadas a partir do disposto na Constituição de 1988, considerando-se, ainda, a realidade doutrinária e pretoriana. É demonstrada a natureza tributánia das contribuiçōes e também de que o problema da finalidade nấo se restringe a elas, mas se estende a todos os tributos. A análise da realidade anterior e posterior à Constituição vigente em relação ao tributo e às contribuições é realizada nas ordens lógica, ontológica e hermenêutica.

A banca examinadora foi composta pelos Professores Doutores: Luiz Felipe Silveira Difini, Professor da Universidade Federal do Rio Grande do Sul e Doutor em Direito pela Universidade Federal do Rio Grande do Sul; José Carlos Francisco, da Universidade Presbiteriana Mackenzie e Doutor em Direito pela Universidade de São Paulo; Heleno Taveira Tôrres, da Faculdade de Direito da Universidade de São Paulo e Doutor em Direito pela Pontifícia Universidade Católica de São Paulo: Paulo Antônio Caliendo Velloso da Silveira, da Pontificia Universidade Católica do Rio Grande do Sule Doutor em Direito pela Pontifícia Universidade Católica de São Paulo e Zélia Luiza Pierdoná, da Universidade Presbiteriana Mackenzie e Doutora em Direito pela Pontifícia Universidade Católica de São Paulo. A referida defesa foi presidida pelo Professor Cezar Saldanha Souza Junior.

Bases para Construção de um Processo Civil Cooperativo - O Direito

Processual Civil no Marco Teórico do Formalismo - Valorativo

Por Daniel Francisco Mitidiero

Data da defesa da tese: $31 / 10 / 2007$ 
Orientador: Carlos Alberto Alvaro de Oliveira

A tese identifica, ao longo da históna do direito processual civil, três modelos possíveis de distribuição das posições jurídicas entre o juiz e as partes: o modelo isonômico, o modelo assimétrico e o modelo cooperativo. Semelhantes modelos são pensados a partir de pressupostos sociais, lógicos e éticos. Nada obstante de tipo ideal, a tese não se furta de apontar exemplos concretos de processos isonômicos (o processo grego antigo e o processo do ordo iudiciarius medieval italiano do século XIV) e de processos assimétricos (o processo da cognitio extra ordinem romano e o processo prussiano moderno do século XVIII). A tese está em que o processo civil cooperativo é o processo do Estado Constitucional. No processo civil pautado pela colaboração, o juiz tem deveres de diálogo, auxilio, prevenção e esclarecimento para com as partes. A tese busca explicitar esses deveres judiciais tomando como base o formalismo do procedimento comum ordinário brasileiro, analisando-o a partir das fases postulatória, de saneamento, instrutória, decisória e recursal.

A banca examinadora foi composta pelos Professores: Adroaldo Furtado Fabricio, Professor da Universidade Federal do Rio Grande do Sul e Doutor em Direito pela mesma instituição; Fredie Souza Didier Junior, Professor da Universidade Federal da Bahia e Doutor em Díreito pela Pontifícia Universidade Católica de São Paulo; José Maria Rosa Tesheiner, Professor da Pontificia Universidade Católica do Rio Grande do Sul e Doutor em Direito pela mesma universidade; José Rogério Cruz e Tucci, Professor da Universidade de São Paulo e Doutor em Direito pela Universitá di Roma, UR, Itália; Ovídio Araújo Baptista da Silva, Professor da Universidade Federal do Rio Grande do Sul e Doutor em Direito pela mesma instituição.

\section{O Princípio da Diferença e o Kantismo na Teoria da Justiça de John} Rawls

Por Voltaire de Freitas Michel

Data da defesa da tese: 30/11/2007

Orientador: Luís Fernando Barzotto

A tese trata de dois temas importantes no interior da Teoria da Justiça de John Rawls: de um lado, o principio da diferença, entendido como o critério que o filosofo reputa válido para a distribuição das desigualdades numa sociedade; de outro, as suas alegadas raizes kantianas, como Rawis expressamente reconhece em seu livro de 1971. Na tese, o 